\title{
Acoustic noise evaluation for overhead line conductors
}

DOI:

10.1109/EIC.2013.6554216

Link to publication record in Manchester Research Explorer

\section{Citation for published version (APA):}

Li, Q., Shuttleworth, R., Zhang, G., Dupere, I., \& Rowland, S. M. (2013). Acoustic noise evaluation for overhead line conductors. In 2013 IEEE Electrical Insulation Conference, EIC 2013/IEEE Electr. Insul. Conf., EIC (pp. 119123). IEEE. https://doi.org/10.1109/EIC.2013.6554216

\section{Published in:}

2013 IEEE Electrical Insulation Conference, EIC 2013|IEEE Electr. Insul. Conf., EIC

\section{Citing this paper}

Please note that where the full-text provided on Manchester Research Explorer is the Author Accepted Manuscript or Proof version this may differ from the final Published version. If citing, it is advised that you check and use the publisher's definitive version.

\section{General rights}

Copyright and moral rights for the publications made accessible in the Research Explorer are retained by the authors and/or other copyright owners and it is a condition of accessing publications that users recognise and abide by the legal requirements associated with these rights.

\section{Takedown policy}

If you believe that this document breaches copyright please refer to the University of Manchester's Takedown Procedures [http://man.ac.uk/04Y6Bo] or contact uml.scholarlycommunications@manchester.ac.uk providing relevant details, so we can investigate your claim.

\section{OPEN ACCESS}


This is a manuscript accepted by IEEE for publication (C) 2013 IEEE. Personal use of this material is permitted. Permission from IEEE must be obtained for all other uses, in any current or future media, including reprinting/republishing this material for advertising or promotional purposes, creating new collective works, for resale or redistribution to servers or lists, or reuse of any copyrighted component of this work in other works. The full reference is:

\section{Acoustic noise evaluation for overhead line conductors'}

Q. Li, R. Shuttleworth, G. Zhang, I. Dupere, S. M. Rowland, IEEE Electrical Insulation Conference, EIC, pp. 119-123 (2013) DOI: $\underline{10.1109 / E I C .2013 .6554216}$ 


\title{
Acoustic Noise Evaluation for Overhead Line Conductors
}

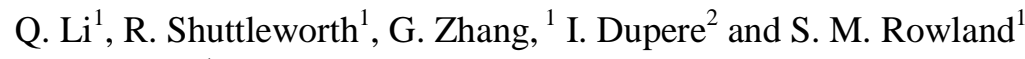 \\ ${ }^{1}$ School of Electrical \& Electronic Engineering \\ ${ }^{2}$ School of Mechanical, Aerospace and Civil Engineering \\ The University of Manchester \\ Manchester, United Kingdom \\ s.rowland@manchester.ac.uk
}

\begin{abstract}
Research work on audible noise emitted from overhead line conductors is reviewed, and a unique experimental set up employing a semi-anechoic chamber and corona cage is described. Acoustically, this facility isolates undesirable background noise and provides a free-field test space inside the anechoic chamber. Electrically, the corona cage simulates a $3 \mathrm{~m}$ section of $400 \mathrm{kV}$ overhead line conductors by achieving the equivalent surface gradient. UV imaging, acoustic measurements and a partial discharge detection system are employed as instrumentation. The acoustic and electrical performance is demonstrated through a series of experiments. One conductor sample is used as an example to illustrate results under various spray conditions.
\end{abstract}

Index Terms-audible noise, overhead line conductor, transmission line, high voltage conductor, anechoic chamber, corona discharge, partial discharge measurement, hum noise, sound pressure level.

\section{INTRODUCTION}

Audible noise is critical design consideration for overhead lines. Power utilities have carried out plenty of experimental measurements to evaluate the noise level emitted from high voltage conductors. Not only outdoor measurements, which are carried out close to whole spans of overhead line, but also indoor measurements which employ cage configurations to simulate sections of overhead line have been reviewed. Processes for measuring audible noise, particularly in lower frequency ranges, will be summarized in the following.

The term 'hum noise' refers to tonal emission which has a key component of twice the power frequency. Since 'hum noise' produced from overhead lines was noticed by Taylor, Chartier and Rice [1] in 1969, its physical mechanism remains a mystery. Although a number of scientific hypotheses [2-11] were introduced to explain the nature of these phenomena, relevant experimental work is still insufficient to identify the primary cause. The difficulty for experimental verification is due to the fact that the $100 \mathrm{~Hz}$ or $120 \mathrm{~Hz}$ (depending on the supply frequency) content cannot be readily measured in the laboratory environment. This is because first of all, the frequency spectrum of the background noise in laboratory

Manuscript received February 28, 2013. This work was supported by National Grid UK. The authors are with The School of Electrical and Electronic Engineering, The University of Manchester, Manchester M60 1QD, UK. (E-mail: s.rowland@ manchester.ac.uk). environment contains peaks at $100 \mathrm{~Hz}$ (or $120 \mathrm{~Hz}$ ) and its harmonics; and secondly, due to the 'magnetostriction effect' [12] on transformer windings, the level of 'hum noise' produced by transformer increases significantly with the level of the leakage current. In order to mitigate the influence of these, an anechoic chamber was designed and built inside the high voltage laboratory in the University of Manchester. The transformer is outside the chamber eliminating this as a source of noise.

This paper introduces various aspects of the design issues including: the electrical design for the cage, the acoustic design for the anechoic chamber and the design of the spray system. The instrumentation of the testing facility includes sound detection, partial discharge measurement, visual corona observation and high speed imaging. Sound Pressure Level is measured through a commercial integrated acoustic detecting platform. This enables accurate detection of time signals and FFT analysis of the frequency spectrum. Partial discharge measurement is carried out through a separate commercial platform which enables the detection of apparent charge and the plot of phase resolved diagrams. High sensitivity ultra violet cameras are employed for visual observation of corona discharge. A high speed camera is used to record the dynamic motion of water droplets on the conductor under the AC electric field.

The sound measurements reported are considered to be the first trials to accurately measure the acoustic emission from conductors within a well controlled laboratory environment. These data will be utilized to help power utilities evaluate various types of conductors and predict the noise level of overhead line structures. The associated electrical measurements, visual and high speed imaging also contribute to the mechanism study of the 'hum noise'.

\section{LITERATURE REVIEW}

The first systematic paper on 'audible noise from transmission lines' was published in 1969 by Taylor, Chartier and Rice [1]. During the following 40 years, sequential works have been carried on by various utilities and universities. An intensive period of publications can be found around the 1980s when EHV transmission lines were in the testing stage. Testing lines for audible noise after 1990 tended to evaluate the noise emission level for novel configurations such as 
asymmetrical bundles, non-parallel bundles etc. Most recent work can be found from China's HVDC testing lines.

Taylor, Chartier and Rice were the first to measure noise level from transmission lines. Their results were obtained from both outdoor and indoor tests under or after rainy conditions. Outdoor tests were carried out at the Apple Grove $750 \mathrm{kV}$ test site [13], while indoor tests were made on "very small dry wires and tubes in the shielded room of the Westinghouse RI Lab". The voltage level for their indoor experiment was 80 $\mathrm{kV}$. The authors concluded that "the major effect of voltage gradient on the sound level occurs in the high range of the frequency spectrum". However, because no effort had been made to mitigate the background noise (especially the $80 \mathrm{kV}$ transformer 'hum'), Teich and Weber queried this conclusion in 2002 [4]. Within Taylor's publication, authors were trying to relate the audible noise level with surface field gradient. However, the method employed for calculating surface gradient is not an accurate method which affects the results and conclusions. There is also no field control method within the indoor test set-up within this early work such as an earthed cage.
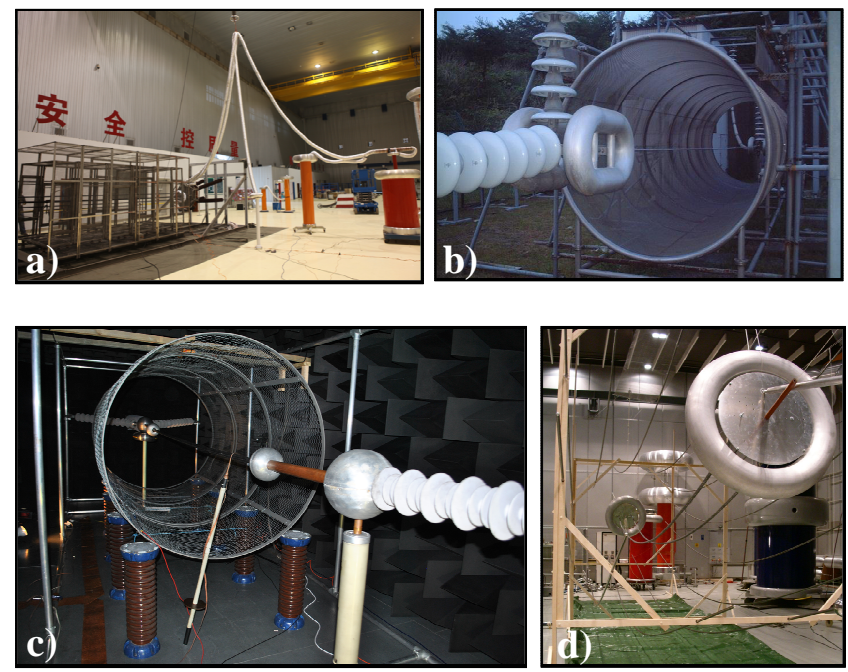

Fig. 1. Various corona cage experiments: a) Tsinghua University; b) JPS; c) University of Manchester; d) ETH.

TABLE I. A COMPARISON OF TEST FACILITIES

\begin{tabular}{|l|l|l|l|l|}
\hline & $\begin{array}{l}\text { Tsinghua } \\
\text { (China) }\end{array}$ & $\begin{array}{l}\text { ETH } \\
\text { (Swiss) }\end{array}$ & $\begin{array}{l}\text { JPS } \\
\text { (Japan) }\end{array}$ & $\begin{array}{l}\text { Manchester } \\
\text { (UK) }\end{array}$ \\
\hline $\begin{array}{l}\text { Length of } \\
\text { Conductor }\end{array}$ & $\begin{array}{l}4 \mathrm{~m} \text { (overall) } \\
3 \mathrm{~m} \text { (effective) }\end{array}$ & $6 \mathrm{~m}$ (overall) & $\begin{array}{l}7.5 \mathrm{~m} \\
\text { (overall) }\end{array}$ & $4 \mathrm{~m}$ (overall) \\
\hline Cage Size & $\begin{array}{l}\text { Square } \\
1.7 \mathrm{~m} * 1.7 \mathrm{~m}\end{array}$ & $\begin{array}{l}12 \text { edge shape } \\
\sim 1.5 \mathrm{~m} \text { radius }\end{array}$ & $\begin{array}{l}\text { Cylinder } \\
1 \mathrm{~m} \text { radius }\end{array}$ & $\begin{array}{l}\text { Cylinder } \\
0.75 \mathrm{~m} \text { radius }\end{array}$ \\
\hline Voltage Level & $90 \sim 130 \mathrm{kV}$ & $166.6 \mathrm{kV}$ & Max 150kV & 90 150kV \\
\hline Surface Stress & $23 \sim 32 \mathrm{kV} / \mathrm{cm}$ & $17.6 \mathrm{kV} / \mathrm{cm}$ & $10 \sim 17 \mathrm{kV} / \mathrm{cm}$ & $16 \sim 25 \mathrm{kV} / \mathrm{cm}$ \\
\hline $\begin{array}{l}\text { Acoustic Noise } \\
\text { Control }\end{array}$ & $\begin{array}{l}\text { Indoor with } \\
\text { no specific } \\
\text { noise control }\end{array}$ & $\begin{array}{l}\text { Indoor with } \\
\text { correction } \\
\text { (background) }\end{array}$ & $\begin{array}{l}\text { Outdoor with } \\
\text { no specific } \\
\text { noise control }\end{array}$ & $\begin{array}{l}\text { Anechoic } \\
\text { chamber with } \\
22.5 \mathrm{dBA}(100 \mathrm{~Hz}) \\
\text { reduction }\end{array}$ \\
\hline $\begin{array}{l}\text { Tensioning } \\
\text { Design }\end{array}$ & $\begin{array}{l}\text { Maximum 2 } \\
\text { tons }\end{array}$ & $\begin{array}{l}\text { No tension } \\
\text { force for } \\
\text { straighten }\end{array}$ & $\begin{array}{l}\text { Load cell unit } \\
\text { for tension }\end{array}$ & Maximum 1 ton \\
\hline $\begin{array}{l}\text { Electrical } \\
\text { Measurements }\end{array}$ & PD, RIV & $\begin{array}{l}\text { Leakage } \\
\text { current }\end{array}$ & No & $\begin{array}{l}\text { PD, RIV, Leakage } \\
\text { current }\end{array}$ \\
\hline $\begin{array}{l}\text { Acoustic } \\
\text { Measurements }\end{array}$ & $\begin{array}{l}\text { Sound level } \\
\text { meter }\end{array}$ & $\begin{array}{l}\text { Sound level } \\
\text { meter with } \\
\text { FFT }\end{array}$ & $\begin{array}{l}\text { Microphone } \\
\text { with FFT }\end{array}$ & $\begin{array}{l}\text { Brüel \& Kjær } \\
\text { PULSE platform } \\
\text { for analysis }\end{array}$ \\
\hline
\end{tabular}

Cage experiments have been well proven to be an effective way to study the environmental impact of transmission lines.

With the help of an 'Experts' Noise Seminar' in the University of Manchester in June 2011, the design criterions for cage experiments have been reviewed in detail. Table I summarizes the design parameters provided by attendees from four leading research institutes.

\section{EXPERIMENTAL DESIGN AND CONSTRUCTION}

\section{A. Design Criterion for the Anechoic Chamber}

There are two factors creating background low frequency noise inside a high voltage laboratory:

- Electrical switching, such as contactors, produces $100 \mathrm{~Hz}$ noise and its harmonics.

- High voltage transformers produce 'hum' (mainly $100 \mathrm{~Hz}$ and its harmonics) due to the 'magnetostriction effect'.

In order to insulate the system from the background noise, the first challenge for an anechoic chamber is to effectively reduce low frequencies. This is achieved by constructing an enclosure using acoustic insulation material.

The second objective is to prevent sound reflections inside the chamber, thereby create a 'free field' for sound measurements. Wedges with sound absorbing material are employed to address this. The overview of the anechoic chamber construction is shown in Figure 2.

\section{B. Design Criterion for the HV Supply}

The design criterion for the HV feed into the chamber is to reduce unwanted corona discharges while maintaining the adequate voltage level for experimental needs. Any protrusions on the high voltage body would initiate corona discharges, especially for joints and terminations, and so must be avoided.

As shown in Fig 3, two corona rings and spheres are introduced to mitigate corona discharge from joints and terminations in the chamber. These stress release devices are tested to ensure they are corona free under high potential. Corona activities are visually detected by UV camera.

The surface gradient distribution for overhead line conductor is reviewed in a recent paper [14]. The voltage level within the experiment is designed to reproduce typical surface gradient values under service.
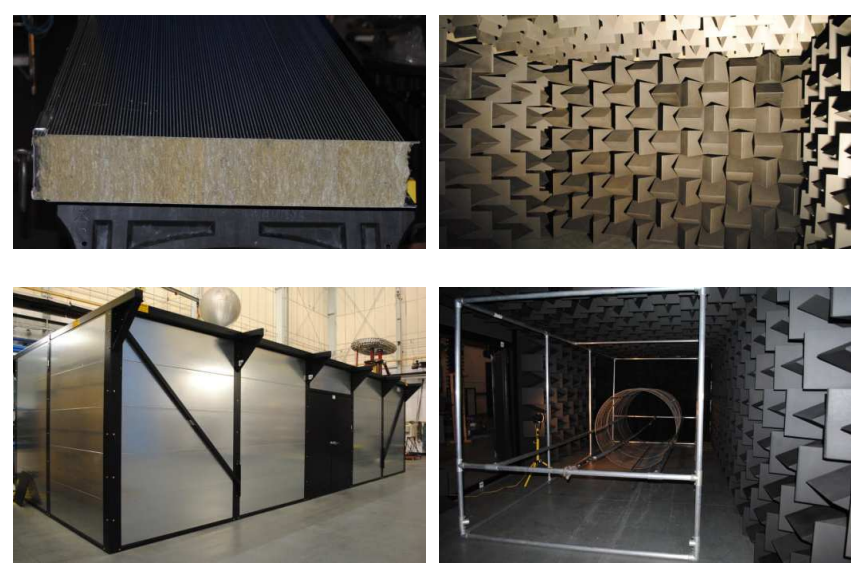

Fig. 2. Sound proofing and anechoic wedges 

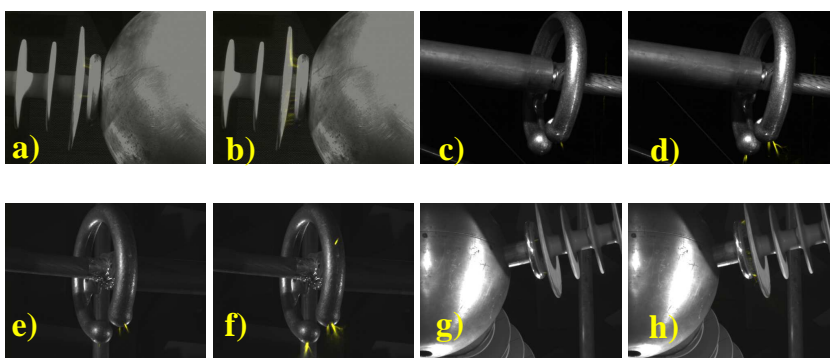

Fig. 3. UV images for corona detection: a) corona inception on sphere-1 at $170 \mathrm{kV}$; b) stable corona on sphere- 1 at $200 \mathrm{kV}$; c) corona inception on stress release ring-1 at $167 \mathrm{kV}$; d) corona inception on stress release ring-1 at $200 \mathrm{kV}$; e) corona inception on stress release ring-2 at $150 \mathrm{kV}$; f) corona inception on stress release ring-2 at $200 \mathrm{kV}$; g) corona inception on sphere-2 at $140 \mathrm{kV}$; h) stable corona on sphere- 2 at $200 \mathrm{kV}$.

The diameter of the corona cage is 1.5 meters. Given a 32 $\mathrm{mm}$ diameter conductor sample, the voltage required for an 18 $\mathrm{kV} / \mathrm{cm}$ surface gradient is around $110 \mathrm{kV}$.

\section{Bushing}

As introduced previously, in order to achieve the sound insulation, a chamber enclosed with sound proof panels is essential. This enclosed chamber is at ground potential and requires a bushing to lead the high voltage through the sound proof panel without violating the acoustic insulation of the anechoic chamber (Fig 4).
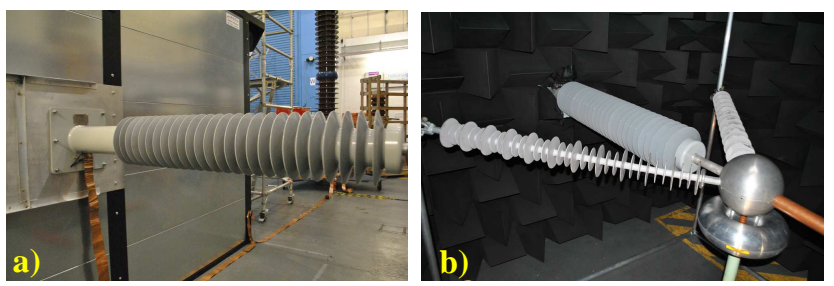

Fig. 4. 250kV HV bushing: a) outside view of bushing; b) inside view of bushing.

\section{Spray Conditions}

There are three wetting conditions used within the experimental facility routinely:
1) manual spray

Uses a bottle sprayer to manually wet the conductor sample on a one-off basis, to apply excessive water droplets on the whole surface of conductor sample (both sessile and pendent drops are formed).

2) continuous light spray

Containers are filled with water and pre-pressurized before experiment. Four nozzles are arranged to provide spray to cover the whole length of conductor sample. The spray can last consistently for ten minutes. The precipitation rate is $21 \mathrm{~mm}$ per hour.

3) continuous heavy spray

Pressurized water feeds four nozzles, covering the whole length of conductor sample. The precipitation rate is $50-60 \mathrm{~mm}$ per hour.

\section{E. Instrumentation}

As highlighted in Fig 5, measurement devices employed in cage experiment include:

- Two ultra violet cameras

- Two free field microphones

- A high speed camera

- A partial discharge detecting system

The UV cameras are employed to visually detect the corona discharges. They are also important tools when mitigating unwanted corona from joints and high voltage terminations.

The two microphones are introduced for acoustic measurements. This set-up allows not only sound pressure level measurements but also sound intensity measurements. Signals are integrated by a data processing front-end which enables FFT analysis and sound intensity computation.

The high speed camera (up to 2000 frames per second for a resolution of $1024 \times 768$ ) produces slow motion video of water droplets behavior within the AC electric field.

The partial discharge detection system is introduced for two functions:

1. To detect the discharge level of the bushing and supply circuit (an undesired noise source).

2. To quantify the apparent charge $\mathrm{Q}_{\mathrm{IEC}}$ of corona discharges.

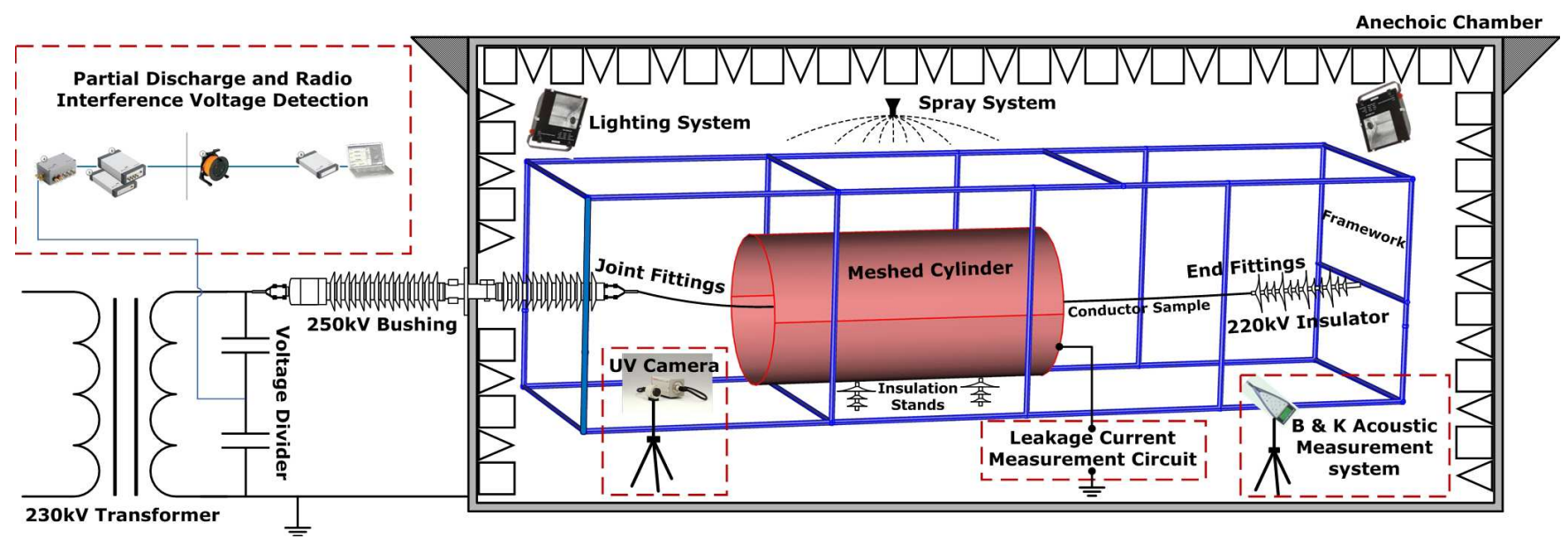

Fig. 5. Instrumentation for the complete cage experiment 


\section{PERFORMANCE OF THE TEST FACILITY}

\section{A. Acoustic Performance of the Anechoic Chamber}

A series of acoustic measurements are carried out to evaluate the performance of the anechoic chamber. There is no existing standard to regulate the measurement for an anechoic chamber, so most of the measurements carried out here refer to the standard for building acoustics (ISO 140-4). The most representative measurements are:

1) sound insulation measurements for background noise

Measurements are taken in ten selected positions, and average result is obtained (shown in Fig 6). There is approximately $22 \mathrm{~dB}$ reduction for the $100 \mathrm{~Hz}$ noise and the A-weighted overall sound pressure level is reduced by $35 \mathrm{dBA}$.

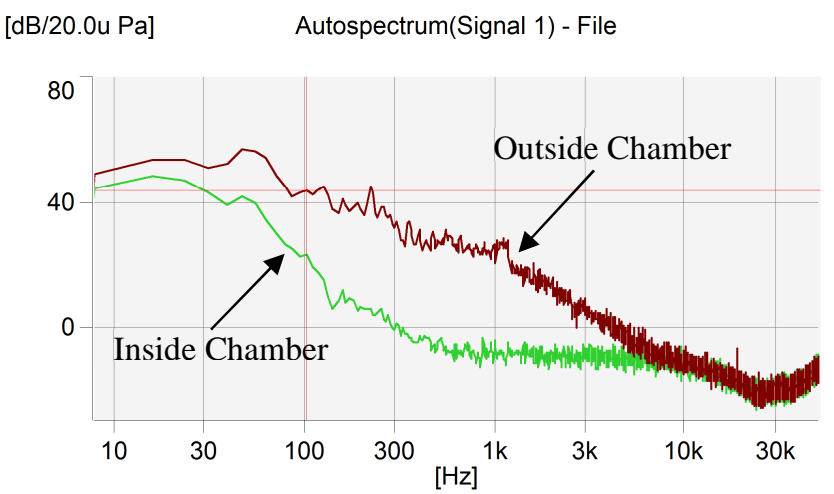

Fig. 6. Background noise mitigation by anechoic chamber

2) reverberation time measurement

The reverberation time is the decay time for sound within the chamber after an impulsive excitation. It is a significant index for the performance of the sound absorbing wedges inside the anechoic chamber. An impulsive sound signal is first applied on a standardized sound source for a short period of time, then is stopped instantaneously. The microphone is utilized to record the sound pressure level for the whole period time to capture the decay curve of sound.

As shown in Fig 7 the impulsive sound signal stops at

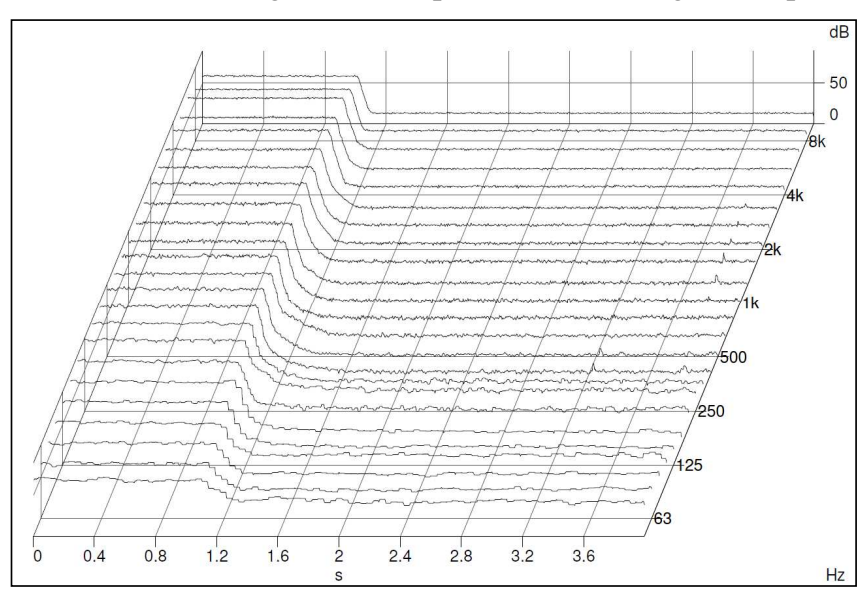

Fig. 7. Reverberation time plot for various frequencies
$1 \mathrm{~s}$, and experienced decay after that. The decay curve for high frequency component $(6 \mathrm{kHz})$ is more rapid than for the low frequency component $(63 \mathrm{~Hz})$ indicating that the low frequency acoustic wave decays more slowly than the high frequency acoustic wave.

\section{B. Partial Discharge Measurement for the HV supply}

The partial discharge (PD) measurement system is employed to detect the PD index from the whole HV supply. Apart from the corona discharge on the surface of conductor sample, there are potentially PD activities from undesired places such as the HV bushing. The PD signal from the HV bushing can be treated as background noise when evaluating the corona discharge level from the conductor sample. Measurements are carried out to evaluate this background PD level when the high voltage supply is solely applied on the HV bushing, and no conductor is under test.

From the phase resolved diagram (Fig 8), the maximum single discharge has an equivalent charge of approximately 1 $\mathrm{nC}$ while other discharge activities are below $1 \mathrm{nC}$. If $\mathrm{Q}_{\text {IEC }}$ is plotted against the applied voltage (Fig 9), the apparent charge according to IEC standard is below $1 \mathrm{nC}$ below $140 \mathrm{kV}$. This indicates that PDs from $\mathrm{HV}$ bushing contribute apparent charge less than $1 \mathrm{nC}$.

Based on the PD bushing test, it is appropriate to choose 1 $\mathrm{nC}$ as the threshold value for conductor samples. The corona discharge inception voltage is defined as the voltage that leads to PD levels exceeding the threshold value.

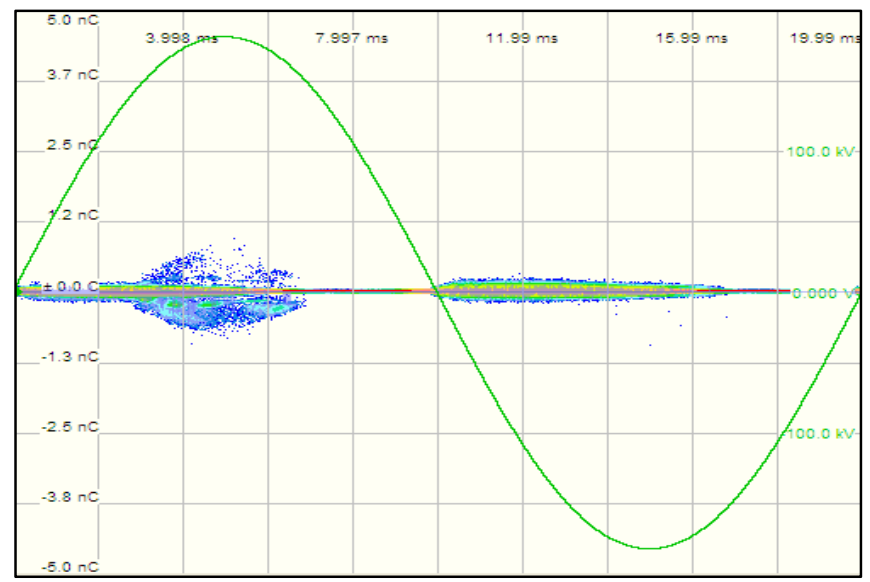

Fig. 8. Phase resolve diagram for bushing test

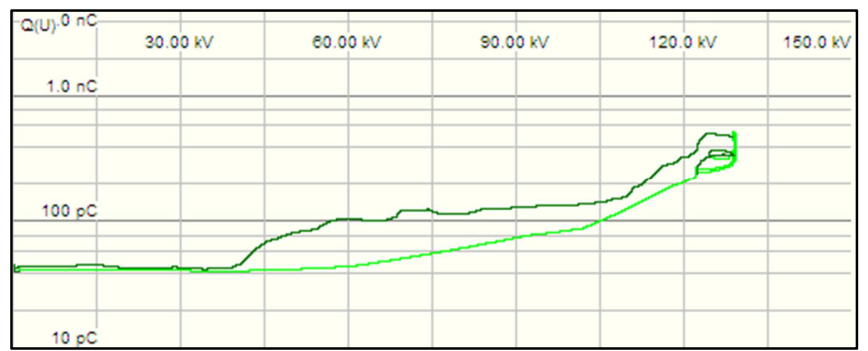

Fig. 9. $Q_{\text {IEC }}$ amplitude with applied voltage level 


\section{RESULTS AND DISCUSSION}

To demonstrate the measurement capability, results are given for one conductor sample.

\section{A. Acoustic Measurement Results}

The A-weighted overall level of sound pressure level (SPL) is plotted against voltage gradient in Fig 10. Three types of spray conditions are compared, and conclusions are:

- below surface stresses of $10 \mathrm{kV} / \mathrm{cm}$, the noise is generated mainly from the spray system: no noise from manual spray, $44 \mathrm{dBA}$ from the light spray and $60 \mathrm{dBA}$ from the heavy spray

- SPLs for manual spray and light spray increase rapidly after the voltage gradient exceeds $10 \mathrm{kV} / \mathrm{cm}$ (noise inception)

- when the voltage gradient is above $15 \mathrm{kV} / \mathrm{cm}$, manual spray and light spray produce similar noise levels due to corona discharge and droplets vibration

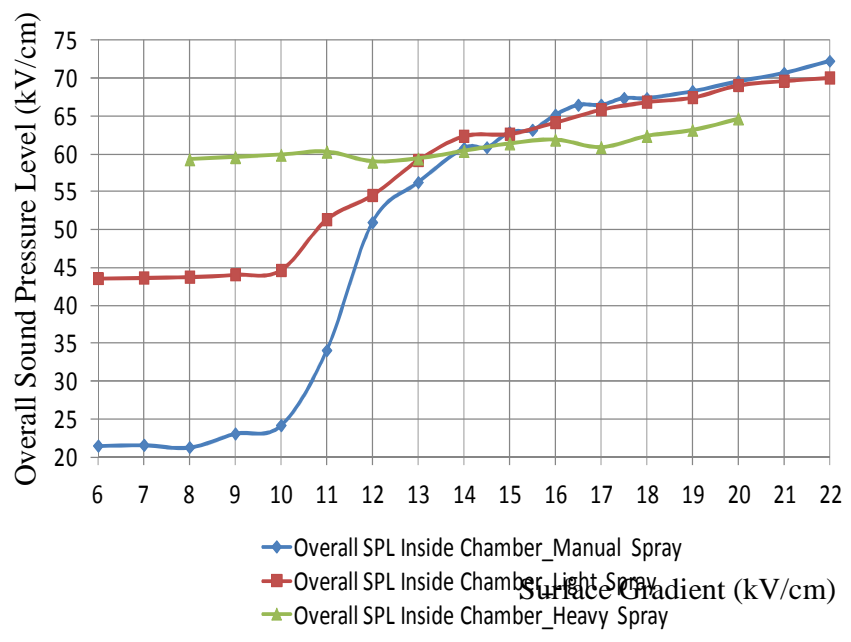

Fig. 10. Overall sound pressure levels plotted against voltage gradient

\section{B. Corona Inception and Extinction}

As introduced previously, the corona threshold $(1 \mathrm{nC})$ is selected above the bushing PD level $(0.8 \mathrm{nC})$. PD detection is carried out through the following procedure:

1) Gradually increase the voltage level until the standardized apparent charge ( $\left.\mathrm{Q}_{\mathrm{IEC}}\right)$ exceeds the threshold value and stable corona discharge is established.

2) Keep the voltage level constant for approximately one minute.

3) Gradually reduce the voltage level until $\mathrm{Q}_{\text {IEC }}$ drops below the threshold value.

In order to maintain reproducibility, this set of tests is repeated ten times and the average value is obtained as shown in Table II.
TABLE II. CORONA INCEPTION AND EXTINGUISHING RESULTS

\begin{tabular}{|c|c|c|c|c|}
\hline & \multicolumn{2}{|c|}{ Dry } & \multicolumn{2}{c|}{ Wet } \\
\cline { 2 - 5 } & $\begin{array}{c}\text { Inception } \\
(\mathrm{kV} / \mathrm{cm})\end{array}$ & $\begin{array}{c}\text { Extinction } \\
(\mathrm{kV} / \mathrm{cm})\end{array}$ & $\begin{array}{c}\text { Inception } \\
(\mathrm{kV} / \mathrm{cm})\end{array}$ & $\begin{array}{c}\text { Extinction } \\
(\mathrm{kV} / \mathrm{cm})\end{array}$ \\
\hline Conductor Sample & 21.6 & 19.8 & 10.1 & 11.4 \\
\hline
\end{tabular}

\section{CONCLUSION}

A test facility has been engineered which is capable of comparing conductor performance under wet and dry conditions. Results are extremely consistent. Uniquely both high frequency and low frequency acoustic emissions can be compared.

\section{ACKNOWLEDGMENT}

The support of National Grid UK in providing the funding for this work is gratefully acknowledged by the authors.

\section{REFERENCES}

[1] E. R. Taylor, V. L. Chartier, D. N. Rice, "Audible Noise and Visual Corona from HV and EHV Transmission Lines and Substation Conductors-Laboratory Tests", IEEE Trans. PAS Vol. 88 (1969), no. 5, pp. 666-679.

[2] EPRI AC Transmission Line Reference Book-200 kV and Above/ Third Edition, Electric Power Research Institute (EPRI), Palo Alto, CA, 2005.

[3] P. S. Maruvada, Corona Performance of High-Voltages Transmission Lines, Ch. 6.6. Baldock, Herts.: Research Studies Press Ltd., 2000, pp. 164-165.

[4] T. H. Teich, H. J. Weber, "Tonal emission from high voltage lines", Proc of 14th Int. Conf on Gas Discharges and Their Appl., Liverpool, UK, Vol. 1, pp. 259-262, 2002.

[5] U. Straumann and M. Semmler, "About the mechanism of tonal emission from high voltage lines", Proc. of 15th Int. Conf. on Gas Discharges and Their Applications, Toulose, France, 2004, Vol. 1, 363366

[6] U. Ingard, "Acoustic wave generation and amplification in a plasma", Phys. Rev., Vol. 145, No. 1, pp. 41-46, 1966.

[7] F. Bastien, "Acoustics and gas discharges: applications to loudspeakers", J. Phys. D: Appl. Phys., Vol. 20, No. 12, pp. 1547-1557 1987.

[8] U. Straumann and J. Fan, "Audible Noise from AC-UHV Transmission Lines-Theoretical Comparison of Broadband and Tonal Components", International Conference on UHV Transmission, Beijing, 2009

[9] U. Straumann, "Mechanism of the tonal emission from ac high voltage overhead transmission lines", J. Phys. D: Appl. Phys., Vol. 44, pp. $75501-755012011$

[10] U. Straumann, "Simulation of the space charge near coronating conductors of AC overhead transmission lines", J. Phys. D: Appl. Phys., Vol. 44, pp. 075502 -075502, 2011

[11] Q. Li, R. Shuttleworth, I. Dupere, G. Zhang, S. M. Rowland, R. S. Morris, "FEA modelling of a water droplet vibrating in an electric field", International Symposium on Electrical Insulation (ISEI), pp. 449-453, 2012

[12] R. B. George, "Power transformer noise: Its characteristics and reduction", A.I.E.E., Trans. March 1931

[13] N. Kolcio, B. J. Ware, R. L. Zagier, V. L. Chartier, F. M. Dietrich, "The Apple Grove $750 \mathrm{kV}$ Project Statistical Analysis of Audible Noise Performance of Conductors at $775 \mathrm{kV}$ ", IEEE Trans. Power Apparatus and Systems, Vol. PAS-93, pp. 831-840, May 1974.

[14] Q. Li, R. Shuttleworth, G. Zhang, S. M. Rowland, R. S. Morris, "On calculating surface potential gradient of overhead line conductors", International Symposium on Electrical Insulation (ISEI), pp. 540-544, 2012 